Research Article

\title{
Efficient Shoot Organogenesis Using Leaf Disc and Nodal Explants of Passion Fruit (Passiflora edulis Sims) and Genetic Fidelity Assessment Using Sequence-Related Amplified Polymorphism (SRAP) Markers
}

\author{
Lydia K. Asande $\mathbb{D}^{\mathbb{1}, 2}$ Omwoyo Ombori, ${ }^{1,}$ Evans N. Nyaboga, ${ }^{2}$ and Richard O. Oduor ${ }^{3}$ \\ ${ }^{1}$ Department of Plant Sciences, Kenyatta University, P.O. Box 43844-00100, Nairobi, Kenya \\ ${ }^{2}$ Department of Biochemistry, University of Nairobi, P.O. Box 30197-00100, Nairobi, Kenya \\ ${ }^{3}$ Department of Biochemistry Microbiology and Biotechnology, Kenyatta University, P. O. Box 43844-00100, Nairobi, Kenya
}

Correspondence should be addressed to Lydia K. Asande; lydasande@yahoo.com

Received 12 March 2020; Revised 14 June 2020; Accepted 19 June 2020; Published 10 July 2020

Academic Editor: Wei Wu

Copyright ( $) 2020$ Lydia K. Asande et al. This is an open access article distributed under the Creative Commons Attribution License, which permits unrestricted use, distribution, and reproduction in any medium, provided the original work is properly cited.

\begin{abstract}
Passion fruit (Passiflora edulis (Sims)) is currently ranked third among fruit exports from Kenya and has great potential since the demand for both fresh fruit and processed juice is on a continuous increase. Passion fruit production in Kenya is constrained by a lack of healthy, clean planting material, poor seed viability, and low germination rates. To address this, the present study reports an in vitro plant regeneration protocol for passion fruit using leaf disc and nodal explants and genetic fidelity analysis of the regenerated plants. The highest number of shoot regeneration was obtained on Murashige and Skoog (MS) medium supplemented with $2 \mathrm{mg} \cdot \mathrm{L}^{-1}$ 6-Benzyl amino purine (BAP) (shoot induction medium). The multiplication of shoots was optimum in MS medium supplemented with $3 \mathrm{mg} \cdot \mathrm{L}^{-1}$ BAP. To eliminate the requirement of an additional step of in vitro rooting, exogenous application of putrescine induced the formation and development of roots on nodal explants. Genetic fidelity analysis of the in vitro regenerated and macropropagated plants with that of the mother plant was carried out by sequence-related amplified polymorphism (SRAP) markers, and monomorphic banding profile for $80 \%$ of the regenerants confirmed the genetic uniformity of the in vitro regenerated and macropropagated plants. The in vitro regeneration system developed can be utilized for mass clonal propagation for the economic commercial exploitation of this important tropical fruit.
\end{abstract}

\section{Introduction}

Passion fruit (Passiflora edulis Sims) is an economically important perennial fruit crop in many tropical and subtropical countries, mainly grown for its edible fruit and ornamental and medicinal use [1-3]. It is a significant component of the horticulture industry which sustains millions of livelihoods in Kenya through local and export markets [4]. Moreover, the crop has great commercial potential in Kenya since the demand for both fresh fruit and processed juice is on the increase besides the expanding export markets [5]. The production of passion fruit in Kenya has remained low at an average of 8 ton $\cdot \mathrm{ha}^{-1}$ compared to a potential of 24 ton $\cdot \mathrm{ha}^{-1}$ mainly due to pests and diseases and inadequate clean planting materials $[4,6]$. These constraints have led to the reduction of the lifespan of the plants in the field from 7 years to an average of 1 to 2 years [4, 7]. Among the diseases limiting passion fruit production is woodiness disease (PWD)-complex which is mainly transmitted by aphids. This is a serious disease in all passion fruit production areas in Kenya, affecting both the purple and the yellow forms $[8,9]$. The disease has been reported to cause up to $100 \%$ loss in fruit yields in Kenya [10]. The mode of propagation entails the use of seed and grafting which has led to the build-up of diseases especially of the woodiness virus complex resulting in total yield losses and lack of clean planting materials. 
The conventional propagation of passion fruit is done through seeds and stem cuttings. The use of seeds is hampered by the poor viability, low germination rate, seed dormancy, and recalcitrant nature of seeds [11]. It is, therefore, necessary to develop alternative methods of clonal propagation for the rapid multiplication of clean planting materials. One of the most appropriate methods of clonal propagation is the use of tissue-culture technology for the production of high-quality and disease-free planting material in a short span of time. There are many reports on in vitro regeneration of different Passiflora species using different types of explants such as root segments, nodes, internodes, and leaf discs [12-14]. At present, there is no report on in vitro regeneration of KPF 4 variety cultivated in Kenya and this hinders genetic improvement of the fruit through biotechnological techniques.

Micropropagation of different plant species through stem nodal cuttings is the most popular and offers production of true-to-type plants in a short period of time and availability of superior individuals for large-scale commercial plantation with quick productive gains $[15,16]$. However, the difficulty in rooting of stem nodal cuttings is an obstacle that needs to be overcome [17]. Polyamines are growth regulators present in all plant tissues and are important for cell division, signal transduction, and protein synthesis [18]. They can speed up or slow down microshoot rooting, depending on their type and concentration. The exogenous use of polyamines on stem cuttings for vegetative propagation has been successful in desert ash [19], sweet orange [20], and Indian soybean [21] and to induce rooting. The role of polyamines in microshoot rooting has also been reported in different plant species [22], of which putrescine has been reported to show a better response compared to other polyamine substances in playing a key role in root growth and development in hard-to-root plants [23]. However, there is no report on the effect of polyamines on the induction of roots on passion fruit stem nodal cuttings. An innovative ex vitro rooting protocol that uses in vitro explants derived from short-term cultures is required to offer an alternative approach for mass propagation of healthy planting materials of passion fruit and at the same time reduces the cost of production of micropropagated plantlets.

Maintaining the genetic stability of in vitro regenerated plants is indispensable before adopting the protocol for large-scale clonal propagation and conservation purposes [24]. Genetic variability can be induced during micropropagation and macropropagation of plants due to the environment and culture conditions and, therefore, it is fundamental to confirm the clonal identity of the regenerated plants using molecular markers [25]. Sequence-Related Amplified Polymorphism (SRAP) is a novel molecular marker technique based on two-primer amplification that preferentially amplifies open reading frames (ORFs) of genes [26]. Due to their unique primer design, SRAP markers are more reproducible, more stable, and highly simple in terms of operation in comparison to other molecular marker techniques [26]. In addition, SRAP markers are more powerful than Simple Sequence Repeats (SSR), Inter-Simple Sequence Repeats (ISSR), or Random Amplified Polymorphic DNA (RAPD) markers in revealing genetic variation between different varieties within a species [27] and are easier to assay than Amplified Fragment Length Polymorphisms (AFLPs) [26]. It has been proven that SRAP is more efficient for identifying epigenetic variations in in vitro cultured plants [28].

The present study was, therefore, carried out with the following objectives: (1) to develop in vitro regeneration system of KPF 4 and purple-skinned varieties of passion fruits grown in Kenya, (2) to evaluate the effect of putrescine on the induction of roots on passion fruit stem nodal cuttings in order to develop a new protocol for ex vitro rooting of passion fruit microshoots, and (3) to analyze the genetic fidelity of in vitro regenerated plants and plantlets propagated from putrescine-treated stem nodal cuttings using SRAP markers.

\section{Materials and Methods}

2.1. Plant Materials and Preparation of Explants. Two passion fruit varieties, namely, Purple and KPF 4, were acquired as ripe fruits as well as potted seedlings from Kenya Agricultural and Livestock Research Organization (KALRO), Thika Horticultural Research Center, and Jomo Kenyatta University of Agriculture and Technology (JKUAT). Mature seeds were extracted from fruits and rinsed with tap water before drying them at approximately room temperature for 3 days. The seeds were surfacesterilized with $70 \%$ (v/v) ethanol for $5 \mathrm{~min}$ followed by $2.5 \%$ sodium hypochlorite for $20 \mathrm{~min}$ and then rinsed four times with sterile distilled water. Approximately $2 \mathrm{~mm}$ cut was carefully made on the lateral sides of each seed before germinating them aseptically in honey jars containing Murashige and Skoog (MS) basal salts [29], 2\% sucrose, and $2.4 \%$ gelrite, $\mathrm{pH} 5.8$, incubated at $27^{\circ} \mathrm{C}$. Leaves from twentyone-day-old seedlings were excised and used as explants for the regeneration of shoots.

\subsection{Regeneration of Shoots from Leaf Disc Explants of Purple} and KPF 4 Varieties of Passion Fruit. Leaf disc segments $\left(6 \mathrm{~mm}^{2}\right)$ were excised from the first two leaves of 21-day-old seedlings and used for in vitro regeneration of shoots. The excised leaf segments were placed in honey jars containing shoot proliferation/induction medium (SIM; MS medium supplemented with $3 \%$ sucrose and $2.4 \%$ gelrite; $\mathrm{pH}$ adjusted to 5.8). The effects of different concentrations of 6-benzyl amino purine (BAP; $1.0-3.0 \mathrm{mg} \cdot \mathrm{L}^{-1}$ ) and $2.0 \mathrm{mg} \cdot \mathrm{L}^{-1} \mathrm{BAP}$ in combination with $0.5 \mathrm{mg} \cdot \mathrm{L}^{-1}$ Kinetin (KIN) were tested on induction and regeneration of shoots [30]. For the control treatment, the medium was not supplemented with PGRs. Cultures were incubated at $28 \pm 2^{\circ} \mathrm{C}$ with a 16 -hour photoperiod for 4 weeks. Microshoots were transferred into MS medium supplemented with $0.1 \mathrm{mg} \cdot \mathrm{L}^{-1}$ BAP, 3\% sucrose, and $2.4 \%$ gelrite, $\mathrm{pH}$ adjusted to 5.8 for 2 weeks for further proliferation before transfer to root initiation and development medium. 
2.3. Rooting of In Vitro Regenerated Plantlets and Acclimatization. The elongated shoots were transferred to the root induction medium consisting of MS supplemented with a $0.1 \mathrm{mg} \cdot \mathrm{L}^{-1}$ naphthaleneacetic acid (NAA) for 4 weeks [30]. In vitro regenerated shoots with roots were taken out of the culture medium and the roots were washed thoroughly, but with care, under running tap water to remove the agar. The plantlets were then transplanted in small pots containing autoclaved garden soil and sand $(1: 1)$. All pots were covered with polyethylene bags to maintain humidity. The potted plantlets were kept under greenhouse conditions. After two weeks, the polyethylene bags were removed and plantlets were kept in the greenhouse. The plantlets were watered at regular intervals as per need. Subsequently, the plantlets were transferred onto larger plastic pots $(14 \times 10.6 \mathrm{~cm}$ size $)$ containing the same potting substrate and kept under greenhouse conditions.

2.4. In Vitro Micropropagation and Multiplication of Plants Using Stem Nodal Explants of KPF 4 Variety of Passion Fruit. Sterile nodal explants about $3 \mathrm{~cm}$ long with 2 nodes were inoculated vertically into MS medium supplemented with different concentrations of $\operatorname{BAP}\left(0,1,2\right.$, and $\left.3 \mathrm{mg} \cdot \mathrm{L}^{-1}\right)$, KIN $\left(0,1,2\right.$, and $\left.3 \mathrm{mg} \cdot \mathrm{L}^{-1}\right)$, and a combination of $2 \mathrm{mg} \cdot \mathrm{L}^{-1} \mathrm{BAP}$ and $0.5 \mathrm{mg} \cdot \mathrm{L}^{-1} \mathrm{KIN}$ for multiple shoot induction [30]. The cultures were incubated at $28 \pm 2{ }^{\circ} \mathrm{C}$ with a 16 -hour photoperiod for 8 weeks. Experiments were set up in a completely randomized design as described by Compton [31]. Each PGR concentration contained 10 replicates, and the experiments were repeated three times. The number of shoots, leaves, and shoot lengths was recorded after a period of 4 weeks and 8 weeks.

2.5. Effect of Putrescine on Root Induction of Nodal Explants of KPF 4 and Purple Varieties under Glasshouse. To determine the effect of putrescine, a polyamine, in the induction of roots in passion fruit, the nodal cuttings ( 2 nodes per explant; approximately 3 to $5 \mathrm{~cm}$ long) from passion fruit seedlings, were treated with different concentrations $(0.5$ and $2 \% \mathrm{w} / \mathrm{v}$ ) of putrescine solutions for 4 hours. For the control treatment, the nodal cuttings were treated with distilled water for 4 hours. The treated nodal cuttings were transferred to plastic pots $(10 \times 7 \mathrm{~cm}$ size $)$ containing sterilized soil mixture. The soil was moistened with tap water and maintained in the greenhouse for root induction for six weeks. High humidity was maintained by covering each pot with a clear transparent polyethylene bag throughout the experimental period. Each treatment had 10 nodal segments and was replicated five times. After 6 weeks, the plants were carefully removed from the pots, soil attached to the plants was removed, and parameters including the percentage response in terms of root induction, number of primary roots per plant, root length, and number of new leaves per plant were recorded.

2.6. Assessment of Genetic Fidelity Using SRAP Markers. Five in vitro regenerated plants were randomly selected from concentrations of PGRs that resulted in the highest number of plants and from the donor mother plants for DNA isolation.

2.7. Genomic DNA Extraction from Leaves. Genomic DNA was extracted from young fresh leaves $(200 \mathrm{mg})$ using cetyltrimethylammonium bromide (CTAB) protocol as described by Saghai-Maroof et al. [32]. To remove RNA, $2 \mu \mathrm{L}$ of RNase A $(10 \mathrm{mg} / \mathrm{ml})$ was added to $20 \mu \mathrm{L}$ of nucleic acidTE buffer mixture and incubated at $37^{\circ} \mathrm{C}$ for $30 \mathrm{~min}$ followed by heating at $65^{\circ} \mathrm{C}$ for $15 \mathrm{~min}$. Agarose gel (1\%; w/v) electrophoresis was used to confirm the quality of genomic DNA. The electrophoresis was run at $80 \mathrm{~V}$ for $45 \mathrm{~min}$. The bands were viewed using an ultraviolet (UV) transilluminator and photographed by a gel documentation system (Bio-Rad). The genomic DNA was dissolved in nuclease-free water and then stored at $-20^{\circ} \mathrm{C}$ for subsequent molecular analysis.

2.8. Sequence-Related Amplified Polymorphism- (SRAP-) PCR Amplification. Twenty different combinations of SRAP markers were initially screened for their ability to amplify passion fruit genomic DNA. Out of the twenty, seven markers were selected based on the production of clear and scorable bands and used for genetic fidelity analysis following amplification of DNA from donor mother plants and in vitro regenerated and macropropagated plants. Amplifications were done in a total volume of $25 \mu \mathrm{L}$ reaction which contained $12.5 \mu \mathrm{L}$ of premix (OneTaq $^{\circledR}$ Quick-Load ${ }^{\circledR}$ 2X Master Mix with Standard Buffer), $9.5 \mu \mathrm{L}$ of nuclease-free PCR water, $1 \mu \mathrm{L}$ of $10 \mu \mathrm{M}$ forward primer, $1 \mu \mathrm{L}$ of $10 \mu \mathrm{M}$ reverse primer, and $1 \mu \mathrm{L}$ of genomic DNA $\left(100 \mathrm{ng} \cdot \mu \mathrm{L}^{-1}\right)$. The PCR cycling conditions were initial denaturation at $94^{\circ} \mathrm{C}$ for 5 min followed by 5 cycles of $1 \mathrm{~min}$ denaturation at $94^{\circ} \mathrm{C}, 1 \mathrm{~min}$ annealing at $35^{\circ} \mathrm{C}$, and $1 \mathrm{~min}$ extension at $72^{\circ} \mathrm{C}$. This was followed by 30 cycles with $1 \mathrm{~min}$ denaturation at $94^{\circ} \mathrm{C}, 1 \mathrm{~min}$ annealing at $50^{\circ} \mathrm{C}$, and $1 \mathrm{~min}$ extension at $72^{\circ} \mathrm{C}$. The program was completed with one final extension at $72^{\circ} \mathrm{C}$ for $7 \mathrm{~min}$ [26]. Three independent amplification reactions were performed using DNA from different extractions from the same plant to assess the consistency and accuracy of the reproducible bands. For accuracy, all experiments were repeated twice. The amplified DNA fragments were run in $1.5 \%(\mathrm{w} / \mathrm{v})$ agarose (Duchefa Biochemie, Netherlands) gel containing 1x TrisAcetate EDTA (TAE) buffer. Ethidium bromide $\left(0.5 \mu \mathrm{g} \cdot \mathrm{L}^{-1}\right)$ was used for the staining of the DNA. Gels visualization was done under a UV transilluminator and photographed by a gel documentation system (Bio-Rad). The amplicon sizes were estimated through comparison with a $1 \mathrm{~kb}$ ladder (Generuler, Thermo Scientific). Only clear and distinct amplified PCR fragments were scored. The bands were scored based on their presence (1) or absence (0) in agarose gels.

2.9. Data Scoring and Analysis. From the generated binary data, the DendroUPGMA server was used in calculating matrix distances between the regenerants and their 
respective donor mother plants. The distance matrices were generated based on Jaccard's similarity coefficient. Similarity matrices were subjected to cluster analysis of the unweighted pair group method with arithmetic mean (UPGMA) and dendrograms constructed using Figure tree software (Version 1.4.2).

Data on in vitro regeneration were analyzed using analysis of variance (ANOVA) and Tukey's Honest significance difference conducted to separate means when ANOVA was significant $(P<0.05)$. GenStat 64 bit release 15.1 was used for data analysis.

\section{Results}

3.1. Effect of BAP and KIN on Shoot Organogenesis from Leaf Disc Explants. Callus was formed from the cut surfaces of the leaf explants cultured on MS medium without growth regulators (control) but no shoots were formed (Table 1). Morphogenetic responses of leaf disc explants were observed on MS medium supplemented with BAP irrespective of the concentration of BAP tested. The first morphogenetic responses were visible after 21 days of culture when shoot buds were observed from the leaf explant (Figure 1). Multiple shoots were obtained from a single leaf explant (Figure 1(a)) and the highest mean number of induced shoots (11.44 per leaf disc explant) was observed on MS supplemented with $2.0 \mathrm{mg} \cdot \mathrm{L}^{-1} \mathrm{BAP}$ and $0.5 \mathrm{mg} \cdot \mathrm{L}^{-1}$ kinetin, which was significantly $(P<0.05)$ different from the other tested concentrations of BAP. There was no significant difference $(P>0.05)$ in the mean number of explants with a cluster of shoots in the media supplemented with $2.0 \mathrm{mg} \cdot \mathrm{L}^{-1}$ BAP compared with that supplemented with $2.0 \mathrm{mg} \cdot \mathrm{L}^{-1} \mathrm{BAP}$ and $0.5 \mathrm{mg} \cdot \mathrm{L}^{-1} \mathrm{KIN}$ (Table 1).

Leaf disc explants cultured on MS medium containing $3 \mathrm{mg} \cdot \mathrm{L}^{-1}$ BAP had the lowest mean number of shoots (4.5) and the mean number of explants with clusters of shoots (0.5) induced (Table 1). Shoots formed on MS medium supplemented with $3 \mathrm{mg} \cdot \mathrm{L}^{-1} \mathrm{BAP}$ were abnormal with short or no stems and large malformed leaves. Microshoots from $2.0 \mathrm{mg} \cdot \mathrm{L}^{-1}$ BAP developed further when they were transferred to $0.1 \mathrm{mg} \cdot \mathrm{L}^{-1}$ BAP (Figures $1(\mathrm{c})$ and $1(\mathrm{~d})$ ). No shoots were initiated from leaf disc explants of purple variety placed on MS medium, supplemented with different concentrations of BAP or a combination of BAP and KIN. All of the leaf disc explants of purple variety turned brown, and no further development into shoot buds was observed.

All elongated shoots developed roots after 1 week (Figure 1(e)) and grew into well-rooted plantlets on MS supplemented with a $0.1 \mathrm{mg} \cdot \mathrm{L}^{-1}$ naphthaleneacetic acid (NAA) in 2 weeks (Figure 1(f)). Fully developed rooted plantlets were hardened for 4 weeks in plastic pots (Figure 1(g)) followed by acclimatization (Figure 1(h)). Plants regenerated through leaf discs had normal growth, and no morphological abnormalities were detected in the early stages of development as observed on the potted plants.

3.2. Effect of Plant Growth Regulators (PGRs) on Multiplication and Elongation of Nodal Explants of KPF 4 Variety of
Passion Fruit. Shoot multiplication was tested on MS medium supplemented with different concentrations of BAP or KIN. On MS medium without PGRs (control), an average of 0.44 and 0.61 shoots per explant were recorded on $4^{\text {th }}$ and $8^{\text {th }}$ weeks of culture, respectively (Table 2 ). MS supplemented with $3 \mathrm{mg} \cdot \mathrm{L}^{-1}$ BAP had the highest mean number of shoots per explant (2.06) while $2 \mathrm{mg} \cdot \mathrm{L}^{-1}$ BAP had the highest average shoot height (0.68). The highest number of leaves per explant (2.11 and 3.61 after the $4^{\text {th }}$ and $8^{\text {th }}$ weeks of culture, respectively) was formed when the media were supplemented with $3 \mathrm{mg} \cdot \mathrm{L}^{-1}$ kinetin (Table 2).

The media supplemented with BAP $\left(2 \mathrm{mg} \cdot \mathrm{L}^{-1}\right)$ in combination with $\mathrm{KIN}\left(0.5 \mathrm{mg} \cdot \mathrm{L}^{-1}\right)$ had the highest average number of shoots per explant (4.44 and 6.39 on the $4^{\text {th }}$ and $8^{\text {th }}$ weeks of culture, respectively) when compared with various concentrations of either BAP or KIN alone.

All the tested concentrations of putrescine induced rooting on nodal cuttings of the two passion fruit cultivars (purple and KPF 4) (Table 3). Putrescine concentration had a significant effect $(P<0.05)$ on the number of roots formed. The purple cultivar had $100 \%$ rooting response in all putrescine treatments while in absence of putrescine rooting it was $66.7 \%$ KPF 4 cultivar had the highest rooting response (100\%) when nodal cuttings were treated with $0.5 \%$ putrescine. There was no induction of roots on nodal cuttings of cultivar KPF 4 which were not treated with putrescine (Figure 2).

3.3. Assessment of Genetic Fidelity of In Vitro Regenerated Plants. Seven SRAP primer combinations produced a total of 1,570 scorable bands ranging from 173 to 260 (Table 4), with an average of 224 bands per primer. The amplified products ranged in size from 130 to $2000 \mathrm{bp}$. The identical banding pattern in the majority of the in vitro regenerated plants with the mother plant (Figure 3) for each of the 7 primer combinations confirmed the genetic fidelity of the in vitro regenerated plants. Dendrogram analysis based on Jaccard's similarity coefficient revealed three clusters (A, B, and C) whose similarity was above $99.96 \%$ (Figure 4 ). The dendrogram generated from SRAP data showed that the in vitro regenerated plants SK4, SK5, SK6, SK7, SK8, SK11, SK12, SK13, SB1, SB3, SB6, SB7, SB8, SB9, SB11, SB12, SBK3, and SBK4 were identical to the mother plant (SBK1) in cluster B (Figure 4). A similarity matrix based on Jaccard's coefficient showed that the pairwise value between the mother plants and the in vitro generated plants ranged from $88.5 \%$ to $100 \%$.

\section{Discussion}

The induction of shoot organogenesis from leaf explant was successfully established for Kenya passion fruit variety (KPF 4) in a medium supplemented with BAP and kinetin. The supplementation of cytokinins in the growth medium is fundamental for shoot induction and development in passion fruit plants $[14,33]$. The presence of BAP in the induction medium was essential for the induction of shoot buds and the development of shoots from leaf disc explants 
TABLE 1: Effect of BAP and KIN on in vitro shoot induction from leaf disc explants of KPF 4 passion fruit variety after 8 weeks of culture.

\begin{tabular}{lcccc}
\hline Plant growth regulator (PGR) & Conc. (mg L $\left.{ }^{-1}\right)$ & $\begin{array}{c}\text { Percentage of explants with } \\
\text { shoots }\end{array}$ & $\begin{array}{c}\text { Mean number of shoots per } \\
\text { explant }\end{array}$ & $\begin{array}{c}\text { Mean number of explants with } \\
\text { clusters of shoots }\end{array}$ \\
\hline & 0.0 & 0.0 & $0.0 \pm 0.0^{a}$ & $0.0 \pm 0.0^{a}$ \\
BAP & 1.0 & 58.0 & $6.06 \pm 0.7^{b}$ & $1.22 \pm 0.1^{b c}$ \\
& 2.0 & 86.6 & $10.72 \pm 0.9^{c}$ & $1.38 \pm 0.2^{c}$ \\
\hline BAP + KIN & 3.0 & 50.0 & $4.5 \pm 0.8^{b}$ & $0.5 \pm 0.1^{a b}$ \\
\hline
\end{tabular}

${ }^{\mathrm{X}}$ Values represent mean \pm standard error of 30 explants per treatment in three repeated experiments. Means with the same letter within a column are not significantly different at $P \geq 0.05$ according to Tukey's Honest significant difference test.

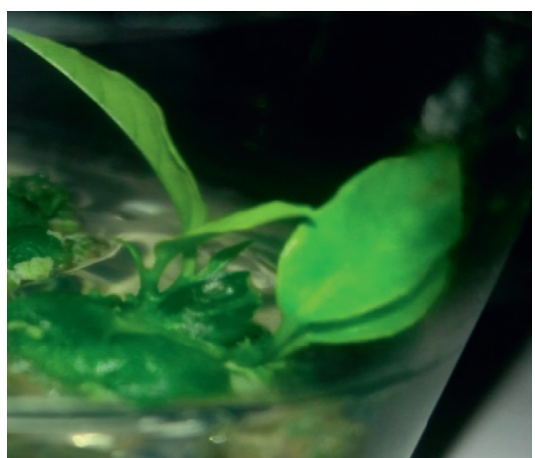

(a)

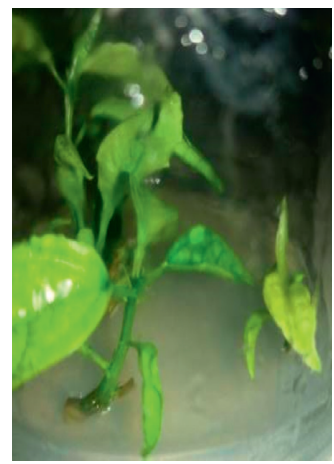

(d)

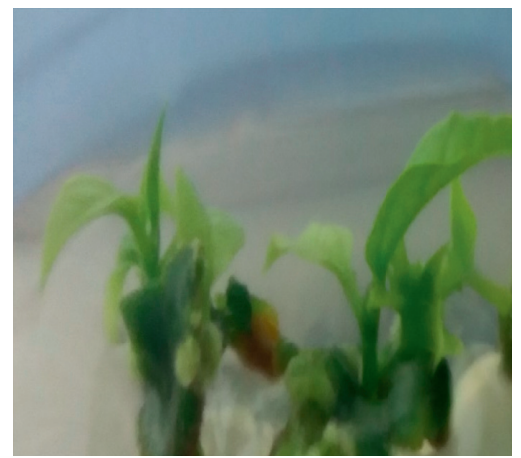

(b)

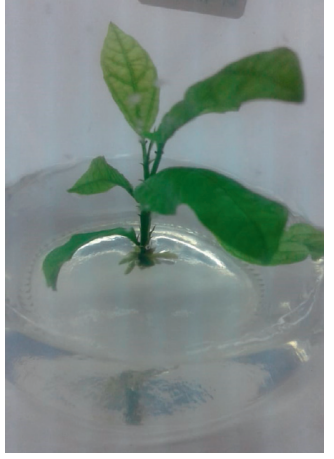

(e)

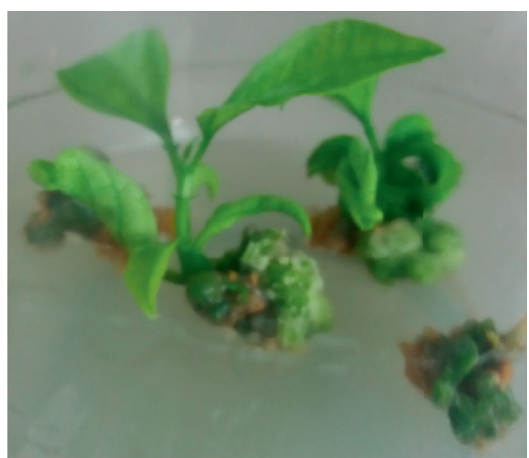

(c)

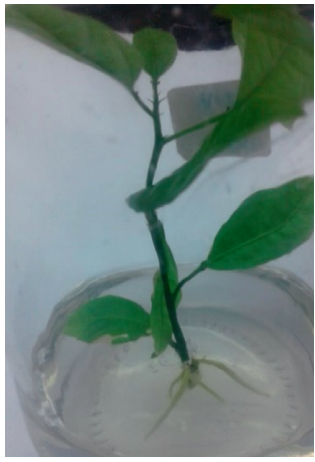

(f)

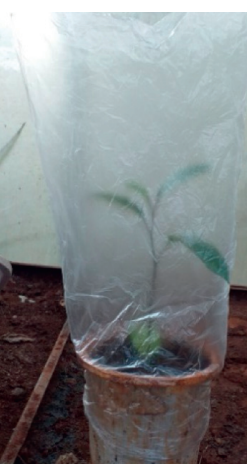

(g)

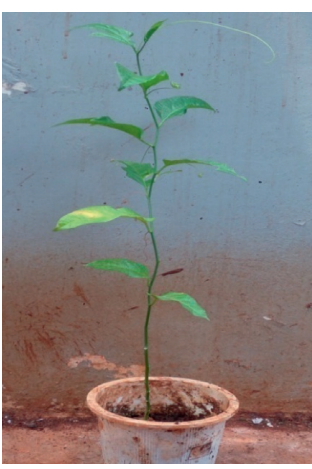

(h)

FIGURE 1: In vitro regeneration of plantlets from leaf disc explants of passion fruit variety KPF 4 cultured on MS medium and acclimatization. (a) and (b) Initiation of shoots from leaf disc explants cultured on MS $+2 \mathrm{mg} \cdot \mathrm{L}^{-1} \mathrm{BAP}$ on the $3^{\text {rd }}$ and $4^{\text {th }}$ weeks after culture, respectively; (c) and (d) further development of shoots on MS $+0.1 \mathrm{mg} \cdot \mathrm{L}^{-1} \mathrm{BAP}$ on the $2^{\text {nd }}$ and $4^{\text {th }}$ weeks after culture, respectively; (e) and (f) rooted plants on $\mathrm{MS}+0.1 \mathrm{mg} \cdot \mathrm{L}^{-1} \mathrm{NAA}$ on the $1^{\text {st }}$ and $2^{\text {nd }}$ weeks after culture, respectively; (g) acclimatization stage (2-week- old plant in a plastic pot); (h) onemonth-old acclimatized plant in a plastic pot. 
TABLE 2: Effect of BAP and KIN on shoot multiplication of nodal explants of KPF 4 variety of passion fruit after 4 and 8 weeks of culture.

\begin{tabular}{|c|c|c|c|c|c|c|c|c|c|}
\hline \multirow[b]{2}{*}{ PGR } & \multirow[b]{2}{*}{$\begin{array}{l}\text { Conc. } \\
\left(\mathrm{mg} \mathrm{L}^{-1}\right)\end{array}$} & \multicolumn{4}{|c|}{4 weeks } & \multicolumn{4}{|c|}{8 weeks } \\
\hline & & $\begin{array}{c}\text { Percentage } \\
\text { no. of } \\
\text { explants } \\
\text { with shoots } \\
(\%)\end{array}$ & $\begin{array}{l}\text { Mean no. of } \\
\text { shoots per } \\
\text { explant }^{X}\end{array}$ & $\begin{array}{l}\text { Mean no. } \\
\text { of leaves }\end{array}$ & $\begin{array}{l}\text { Shoot height } \\
(\mathrm{cm})^{\mathrm{X}}\end{array}$ & $\begin{array}{l}\text { Percentage } \\
\text { no. of } \\
\text { explants } \\
\text { with shoots } \\
(\%)\end{array}$ & $\begin{array}{l}\text { Mean no. of } \\
\text { shoots per } \\
\text { explant }^{\mathrm{X}}\end{array}$ & $\begin{array}{l}\text { Mean no. of } \\
\text { leaves }\end{array}$ & $\begin{array}{l}\text { Mean shoot } \\
\text { height }(\mathrm{cm})^{\mathrm{X}}\end{array}$ \\
\hline \multirow{4}{*}{ BAP } & 0.0 & 44.0 & $0.44 \pm 0.1^{a}$ & $0.28 \pm 0.1^{a}$ & $0.04 \pm 0.01^{a}$ & 55.0 & $0.61 \pm 0.12^{a}$ & $0.72 \pm 0.18^{a}$ & $0.07 \pm 0.02^{a}$ \\
\hline & 1.0 & 94.4 & $0.95 \pm 0.1^{a b}$ & $1.95 \pm 0.3^{b}$ & $0.16 \pm 0.02^{a b}$ & 100.0 & $1.0 \pm 0.0^{a}$ & $3.57 \pm 0.31^{c}$ & $0.85 \pm 0.16^{c}$ \\
\hline & 2.0 & 100.0 & $1.0 \pm 0.0^{a b}$ & $3.44 \pm 0.2^{c}$ & $0.68 \pm 0.07^{d}$ & 100.0 & $1.06 \pm 0.05^{a}$ & $5.0 \pm 0.23^{d}$ & $1.51 \pm 0.11^{d}$ \\
\hline & 3.0 & 94.4 & $2.06 \pm 0.3^{b}$ & $1.83 \pm 0.3^{b}$ & $0.22 \pm 0.04^{a b}$ & 100.0 & $3.83 \pm 0.44^{b}$ & $3.33 \pm 0.37^{c}$ & $0.83 \pm 0.11^{c}$ \\
\hline \multirow{3}{*}{ KIN } & 1.0 & 94.4 & $0.94 \pm 0.1^{a b}$ & $1.06 \pm 0.2^{a b}$ & $0.16 \pm 0.03^{a b}$ & 100.0 & $1.0 \pm 0.0^{a}$ & $1.72 \pm 0.34^{a b}$ & $0.36 \pm 0.08^{a b}$ \\
\hline & 2.0 & 100.0 & $1.0 \pm 0.0^{a b}$ & $1.22 \pm 0.2^{a b}$ & $0.23 \pm 0.04^{a b c}$ & 100.0 & $1.0 \pm 0.0^{a}$ & $2.28 \pm 0.36^{b c}$ & $0.57 \pm 0.09^{b c}$ \\
\hline & 3.0 & 100.0 & $1.0 \pm 0.0^{a b}$ & $2.11 \pm 0.3^{b}$ & $0.46 \pm 0.08^{c d}$ & 100.0 & $1.0 \pm 0.0^{a}$ & $3.61 \pm 0.35^{c}$ & $0.85 \pm 0.10^{c}$ \\
\hline $\mathrm{BAP}+\mathrm{KIN}$ & $2.0+0.5$ & 94.0 & $4.44 \pm 0.8^{c}$ & $1.89 \pm 0.2^{b}$ & $0.36 \pm 0.09^{b c}$ & 100.0 & $6.39 \pm 0.86^{c}$ & $3.06 \pm 0.30^{b c}$ & $0.53 \pm 0.10^{a b c}$ \\
\hline
\end{tabular}

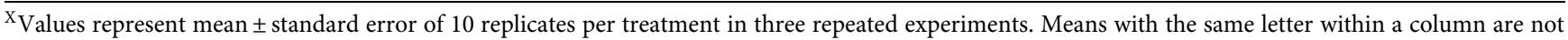
significantly different at $P>0.05$ according to Tukey's Honest significant difference test.

TABLE 3: Effect of putrescine on rooting of nodal explants of KPF 4 and purple passion fruit varieties.

\begin{tabular}{lccccc}
\hline $\begin{array}{l}\text { Passion fruit } \\
\text { variety }\end{array}$ & Conc. of putrescine (\%) & $\begin{array}{c}\text { Percentage rooting response } \\
(\%)\end{array}$ & $\begin{array}{c}\text { Mean no. of roots }{ }^{\mathrm{X}} \\
\text { Murple }\end{array}$ Mean root length $^{\mathrm{X}} \begin{array}{c}\text { Mean no. of new } \\
\text { leaves }\end{array}$ \\
\hline \multirow{3}{*}{ PPF 4} & 0.0 & 66.7 & $3.33 \pm 1.2^{a}$ & $1.2 \pm 0.6^{a}$ & $0.0^{a}$ \\
& 2.0 & 100 & $10.6 \pm 1.0^{b c}$ & $5.8 \pm 0.7^{c}$ & $3.8 \pm 0.3^{b}$ \\
& 0.0 & 100 & $11.2 \pm 0.8^{b c}$ & $5.5 \pm 0.8^{b c}$ & $3.8 \pm 0.3^{b}$ \\
\hline
\end{tabular}

${ }^{\mathrm{X}}$ Values represent mean \pm standard error of 10 replicates per treatment in three repeated experiments. Means with the same letter within a column are not significantly different at $P \geq 0.05$ according to Tukey's Honest significant difference test.

of KPF 4. The in vitro regeneration studies in other passion fruit species such as $P$. edulis $f$. flavicarpa, $P$. caerulea, $P$. alata, and $P$. setacea described the crucial role of BAP in shoot formation from leaf explants [33-36]. When leaf disks of purple passion fruit were cultured on MS with all the concentrations of BAP tested, no shoot buds were induced. This finding supports the assumption that shoot organogenesis in passion fruit is genotype-specific. The genotypic effect on the shoot organogenesis of passion fruit varieties tested in this study was also observed by Amugune et al. [30] and Mukasa et al. [37].

This suggests that the regeneration process needs to be optimized and standardized for each passion fruit variety.

Shoot multiplication from nodal explants of KPF 4 variety of passion fruit grown in Kenya was successfully established in which inclusion of BAP in the shoot multiplication medium was necessary for nodal explants of KPF 4 variety. This is in agreement with the findings by Busilacchi et al. [35] and Ozarowski and Thiem [38] on Passiflora caerulea. BAP has the potential to shift the apical dominance toward the development of lateral buds, which causes cell division to occur in meristem cells, hence enhancing the number of branches and amplifying the rate of cell division in the lateral buds of nodal explants [39].
Findings from the present study show that $3 \mathrm{mg} \cdot \mathrm{L}^{-1} \mathrm{BAP}$ was also found to be superior to $3 \mathrm{mg} \cdot \mathrm{L}^{-1}$ Kinetin in the multiplication of shoots after 8 weeks of culture. This is consistent with findings documented by Ragavendran et al. [40] who demonstrated that, compared to TDZ and KIN, BAP was more efficient in shoot regeneration of Passiflora foetida.

In the present study, rooting was successfully induced on both concentrations of putrescine suggesting that polyamine plays a significant role in promoting root initiation in passion fruit varieties. This is in agreement with Couee et al. [41], Viu et al. [42], Parimalan et al. [43], and Redha and Suleman [44] who reported the involvement of polyamines in adventitious and lateral root formation and that putrescine enhances root initiation and development. In the putrescine-free control treatment, roots were recorded only on purple passion fruit nodal explants but no roots were recorded on KPF 4 nodal explants, indicating that root formation is genotype-dependent or might be due to variation in endogenous putrescine levels. However, the number and length of roots in the putrescine treatment were significantly higher compared to the roots formed in putrescine-free treatment. The present study demonstrates that nodal explants of in vitro derived shoots of passion fruit can be exploited for mass multiplication of plantlets 


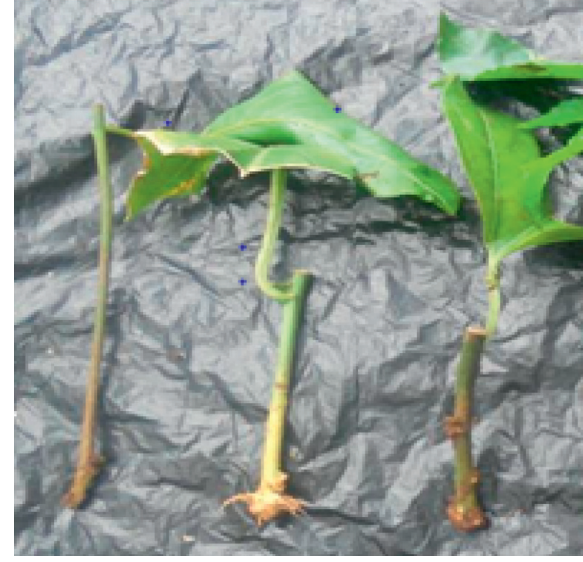

(a)

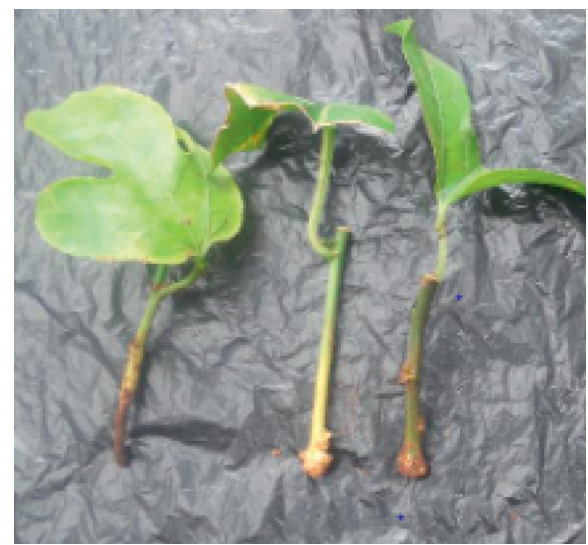

(c)

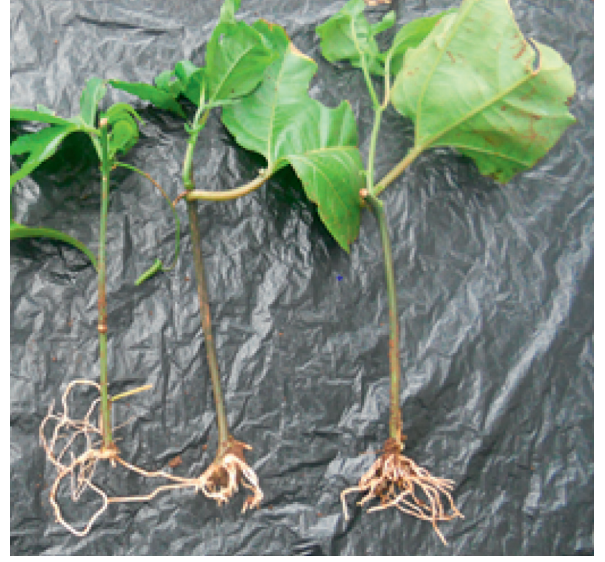

(b)

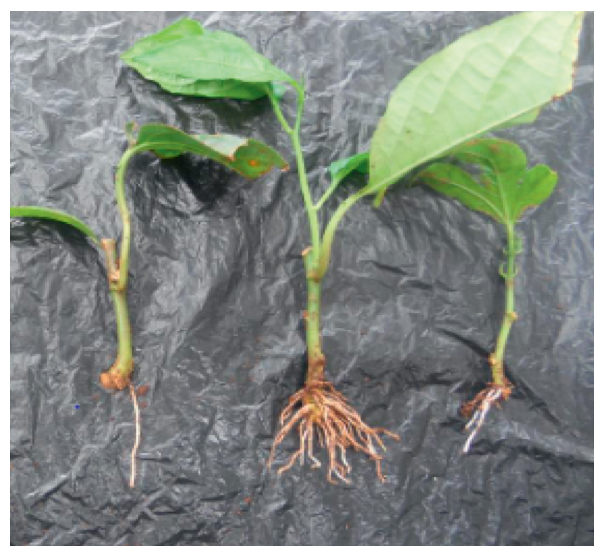

(d)

Figure 2: Root initiation from passion fruit stem nodal explants treated with different concentrations of putrescine: (a) purple-skinned passion fruit nodal explants not treated with putrescine; (b) purple-skinned passion fruit nodal explants treated with $2 \%$ putrescine treatment; (c) KPF 4 nodal stem explants not treated with putrescine; (d) KPF 4 nodal stem explants treated with $2 \%$ putrescine treatment.

TABLE 4: Details of SRAP primer combinations showing the number and size of amplified fragments generated in tested plants.

\begin{tabular}{|c|c|c|c|c|}
\hline Primer code & Forward sequence $\left(5^{\prime}\right.$ to $\left.3^{\prime}\right)$ & Reverse sequence $\left(5^{\prime}\right.$ to $\left.3^{\prime}\right)$ & No. of scorable bands & Range of band sizes (bp) \\
\hline me 1 -em 9 & TGAGTCCAACCGGATA & GACTGCGTACGAATTCAG & 234 & $400-800$ \\
\hline me 5-em 7 & TGAGTCCAAACCGGAAG & GACTGCGTACGAATTCAA & 260 & $300-2000$ \\
\hline me 2 -em 10 & TGAGTCCAAACCGGAGC & GACTGCGTACGAATTCAG & 205 & $300-2000$ \\
\hline me 1 -em 12 & TGAGTCCAACCGGATA & GACTGCGTACGAATTCTC & 208 & $250-2000$ \\
\hline me $11-$ em 11 & TGAGTCCAAACCGGTCC & GACTGCGTACGAATTCCA & 260 & $400-1000$ \\
\hline me 1 -em 15 & TGAGTCCAACCGGATA & GACTGCGTACGAATTGTC & 230 & $130-650$ \\
\hline me 2-em 12 & TGAGTCCAAACCGGAGC & GACTGCGTACGAATTCTC & 173 & $150-600$ \\
\hline
\end{tabular}

accompanied by better rooting with the utilization of polyamines in the glasshouse.

Genetic fidelity of in vitro regenerated plants is an essential step in the utilization of the protocol for mass multiplication of planting materials and as a prerequisite for genetic transformation for improved agronomic traits. In this study, SRAP profiles of $80 \%$ of in vitro regenerated and macropropagated plantlets tested were monomorphic. This suggests the genetic stability of the majority of the plantlets. Lack of polymorphism in the majority of the in vitro regenerated plants indicates that the plants were true- to-type, and therefore no significant somaclonal variation resulted from the in vitro regenerated plants. According to Vidal and Garcia [45], shoots initiated from nodal explants are superior for clonal propagation due to preserved genetic stability as the plantlets are less prone to genetic changes that occur during cell development under in vitro conditions. Since not all in vitro regenerated plants were identical to the mother plant in this study, we propose the inclusion of genetic stability as an indicator of the reliability in the development of passion fruit regeneration methodologies. 


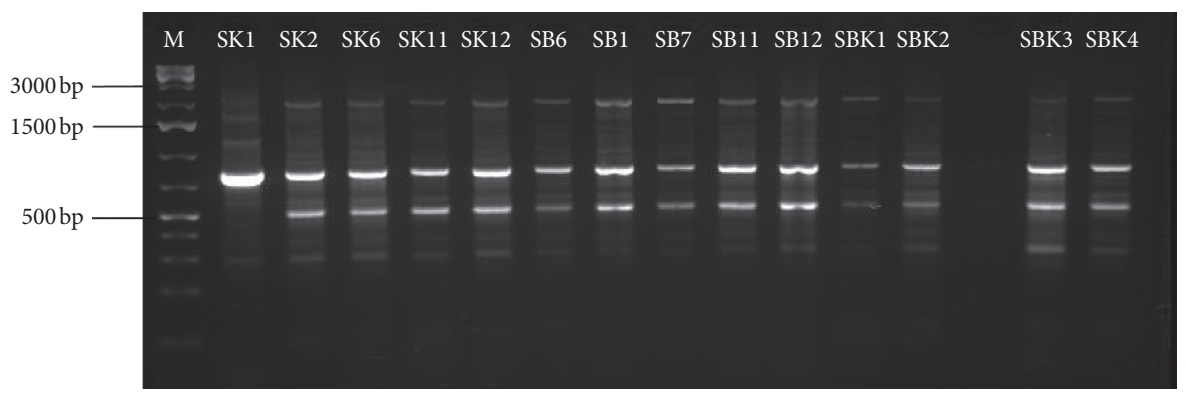

FIGURE 3: SRAP amplification profiles of mother plants and randomly selected in vitro regenerated of passion fruit of KPF 4 variety. Lane L is a $1 \mathrm{~kb}$ plus molecular weight DNA marker (Generuler, Thermo scientific); Lanes, SK1 and SK2, are plantlets micropropagated on MS $+1 \mathrm{mg} \cdot \mathrm{L}^{-1} \mathrm{KIN}$; SK6 is a plantlet micropropagated on $\mathrm{MS}+2 \mathrm{mg} \cdot \mathrm{L}^{-1} \mathrm{KIN}$; SK11 and SK12 are plantlets micropropagated on MS + $3 \mathrm{mg} \cdot \mathrm{L}^{-1} \mathrm{KIN}$; SB6 represents a mother plant; SB1 is a plantlet micropropagated on $\mathrm{MS}+1 \mathrm{mg} \cdot \mathrm{L}^{-1} \mathrm{BAP}$; SB7 is a plantlet micropropagated on MS $+2 \mathrm{mg} \cdot \mathrm{L}^{-1} \mathrm{BAP}$; SB11 and SB12 are plantlets regenerated on MS $+3 \mathrm{mg} \cdot \mathrm{L}^{-1} \mathrm{BAP}$; SBK1, SBK 2, and SBK 3 are plantlets micropropagated on MS supplemented with $2 \mathrm{mg} \cdot \mathrm{L}^{-1} \mathrm{BAP}+0.5 \mathrm{mg} \cdot \mathrm{L}^{-1} \mathrm{KIN}$; SBK 4 represents a mother plant.

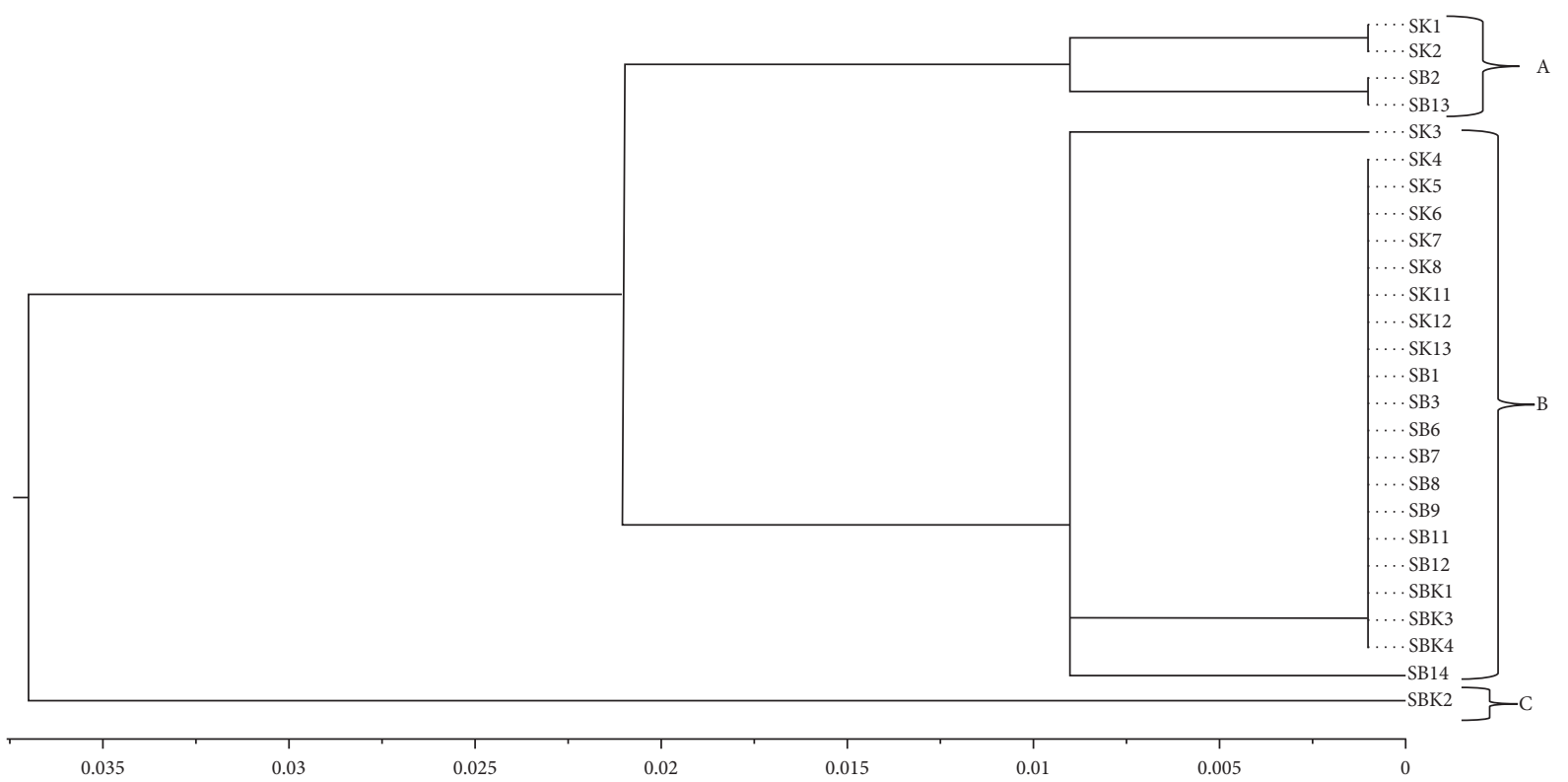

FIGURE 4: Dendrogram illustrating coefficient similarity among in vitro regenerated plants and mother plants (SB6 and SBK4) of passion fruit KPF 4 by UPMGA cluster analysis of SRAP data set showing a genetic relationship. SK1, SK2, SK3, SK4, and SK5 represent plants in vitro micropropagated on MS supplemented with $1 \mathrm{mg} \cdot \mathrm{L}^{-1} \mathrm{KIN}$. SK6, SK7, and SK8 represent plants in vitro micropropagated on MS supplemented with $2 \mathrm{mg} \cdot \mathrm{L}^{-1} \mathrm{KIN}$. SK11, SK12, and SK13 represent plants in vitro micropropagated on MS supplemented with 3 mg. $\mathrm{L}^{-1}$ KIN. SB1, SB2, and SB3 represent plants in vitro regenerated on MS supplemented with $1 \mathrm{mg} \cdot \mathrm{L}^{-1} \mathrm{BAP}$. SB6 is a mother plant; SB7, SB8, and SB9 represent plants in vitro regenerated on MS supplemented with $2 \mathrm{mg} \cdot \mathrm{L}^{-1} \mathrm{BAP}$. SB11, SB12, SB13, and SB14 represent plants in vitro micropropagated on MS supplemented with $3 \mathrm{mg} \cdot \mathrm{L}^{-1}$ BAP. SBK 1, SBK2, and SBK3 represent plants in vitro regenerated on MS supplemented with $2 \mathrm{mg} \cdot \mathrm{L}^{-1} \mathrm{BAP}$ and $0.5 \mathrm{mg} \cdot \mathrm{L}^{-1} \mathrm{KIN}$ while SBK4 represents the mother plant.

\section{Conclusions}

This study demonstrates an efficient, rapid, and reproducible in vitro plant regeneration protocol for passion fruit using leaf disc explants. Exogenous application of polyamine (putrescine) played a key role in promoting the induction of roots on stem nodal explants of passion fruit. The results of this study revealed that the majority ( $80 \%)$ of in vitro regenerated plants were genetically identical to the mother plant. The protocol can be applied for large-scale production of tissue-culture passion fruit microplants for subsequent hardening to generate clean planting material for farmers.

\section{Data Availability}

The data used to support the findings of this study are incorporated within the article.

\section{Conflicts of Interest}

The authors state that they have no conflicts of interest.

\section{Authors' Contributions}

LKA carried out all the experiments and wrote the first draft of the manuscript. OO, ENN, and ROO were involved in 
experimental design, data analysis, supervision of the work, and review of the manuscript. All authors read and approved the final version of the manuscript.

\section{Acknowledgments}

This study was supported by the Government of Kenya through the National Research Fund (grant for the financial year 2016/2017).

\section{References}

[1] S. Zibadi and R. R. Watson, "Passion fruit (Passiflora edulis)," Evidence-Based Integrative Medicine, vol. 1, no. 3, pp. 183-187, 2004.

[2] C. C. Pereira, J. R. M. Rufino, A. C. Habert, R. Nobrega, L. M. C. Cabral, and C. P. Borges, "Aroma compounds recovery of tropical fruit juice by pervaporation: membrane material selection and process evaluation," Journal of Food Engineering, vol. 66, no. 1, pp. 77-87, 2005.

[3] A. C. Mwita, "Assessment of profit efficiency among sweet yellow passion fruit farmers in Mbeere South, Embu County," Kenyatta University, Nairobi, Kenya, Doctoral dissertation, 2016.

[4] C. Gichimu, M. Mwangi, and I. Macharia, "Assessment of passion fruit orchard management and farmers' technical efficiency in central-eastern and north-rift highlands, Kenya," Journal of Economics and Sustainable Development, vol. 4, no. 10, 2013.

[5] C. W. Wangungu, M. Mwangi, R. Gathu, R. Muasya, J. Mbaka, and N. Kori, "Reducing dieback disease incidence of passion fruit in Kenya through management practices," in Proceedings of the African Crop Science Conference, vol. 10, pp. 499-502, Kampala, Uganda, 2011.

[6] D. R. Barros, "Análise comparativa do genoma de dois isolados de Cowpea aphid-borne mosaic virus (CABMV) provenientes de diferentes hospedeiros," Thesis, Doutorado em Fitopatologia, Universidade Federal de Viçosa, Viçosa, Brazil, 2007.

[7] J. Morton, "Passion fruit," Fruits of Warm Climates, pp. 320-328, Echo Point Books \& Media, Miami, FL, USA, 1987.

[8] D. C. Kilalo-Ngeranwa, "Molecular detection of viruses associated with passion fruit (Passiflora edulis Sims) woodiness disease, monitoring and management of aphid vectors in Kenya," University of Nairobi, Nairobi, Kenya, Doctoral dissertation, 2012.

[9] Horticultural Crops Development Authority (HCDA), Horticultural Validated Report, HCDA, Nairobi, Kenya, 2013.

[10] R. L. Amata, M. J. Otipa, M. Waiganjo, and J. Wabule, "Incidences, prevalence and severity of passion fruit fungal diseases in major production regions of Kenya," Journal of Applied Biosciences, vol. 20, pp. 1146-1152, 2009.

[11] R. M. Mabundza, P. Wahome, and M. Masarirambi, "Effects of different pre-germination treatment methods on the germination of passion (Passiflora edulis) seeds," Journal of Agriculture, Forestry and the Social Sciences, vol. 6, p. 57, 2010.

[12] S. P. Lombardi, I. R. D. S. Passos, M. C. S. Nogueira, and B. Appezzato-da-Glória, "In vitro shoot regeneration from roots and leaf discs of Passiflora cincinnata mast," Brazilian Archives of Biology and Technology, vol. 50, no. 2, pp. 239-247, 2007.

[13] D. I. Rocha, L. M. Vieira, F. A. O. Tanaka, L. C. d. Silva, and W. C. Otoni, "Anatomical and ultrastructural analyses of in vitro organogenesis from root explants of commercial passion fruit (Passiflora edulis Sims)," Plant Cell, Tissue and Organ Culture (PCTOC), vol. 111, no. 1, pp. 69-78, 2012.

[14] Y. B. C. J. Rosa, C. C. Monte-Bello, and M. C. Dornelas, "In vitro organogenesis and efficient plant regeneration from root explants of Passiflora suberosa L. (Passifloraceae)," In Vitro Cellular \& Developmental Biology-Plant, vol. 52, no. 1, pp. 64-71, 2016.

[15] V. Kesari, A. Krishnamachari, and L. Rangan, "Effect of auxins on adventitious rooting from stem cuttings of candidate plus tree Pongamia pinnata (L.), a potential biodiesel plant," Trees, vol. 23, no. 3, pp. 597-604, 2009.

[16] A. Pandey, S. Tamta, and D. Giri, "Role of auxin on adventitious root formation and subsequent growth of cutting raised plantlets of Ginkgo biloba L," International Journal of Biodiversity and Conservation, vol. 3, no. 4, pp. 142-146, 2011.

[17] D. K. Isutsa, "Rapid micro propagation of passion fruit (Passiflora edulis Sims.) varieties," Scientia Horticulturae, vol. 99, no. 3-4, pp. 395-400, 2004.

[18] T. Kusano, T. Berberich, C. Tateda, and Y. Takahashi, "Polyamines: essential factors for growth and survival," Planta, vol. 228, no. 3, pp. 367-381, 2008.

[19] G. Tonon, C. Kevers, and T. Gaspar, "Changes in polyamines, auxins and peroxidase activity during in vitro rooting of Fraxinus angustifolia shoots: an auxin-independent rooting model," Tree Physiology, vol. 21, no. 10, pp. 655-663, 2001.

[20] A. F. S. Mendes, L. C. Cidade, W. C. Otoni, W. S. Soares-Filho, and M. G. C. Costa, "Role of auxins, polyamines and ethylene in root formation and growth in sweet orange," Biologia Plantarum, vol. 55, no. 2, pp. 375-378, 2011.

[21] M. Arun, K. Subramanyam, J. Theboral, A. Ganapathi, and M. Manickavasagam, "Optimized shoot regeneration for Indian soybean: the influence of exogenous polyamines," Plant Cell, Tissue and Organ Culture (PCTOC), vol. 117, no. 2, pp. 305-309, 2014.

[22] M. E. Arena, G. M. Pastur, M. P. Benavides, and N. Curvetto, "Polyamines and inhibitors used in successive culture media forin vitrorooting inBerberis buxifolia," New Zealand Journal of Botany, vol. 43, no. 2, pp. 373-380, 2005.

[23] Q. S. Wu, Y. N. Zou, and X. H. He, "Exogenous putrescine, not spermine or spermidine, enhances root mycorrhizal development and plant growth of trifoliate orange (Poncirus trifoliata) seedlings," International Journal of Agriculture and Biology, vol. 12, pp. 576-580, 2010.

[24] S. Jin, R. Mushke, H. Zhu et al., "Detection of somaclonal variation of cotton (Gossypium hirsutum) using cytogenetics, flow cytometry and molecular markers," Plant Cell Reports, vol. 27, no. 8, pp. 1303-1316, 2008.

[25] P. K. Gupta and J. K. Roy, "Molecular markers in crop improvement: present status and future needs in India," Plant Cell, Tissue and Organ Culture, vol. 70, no. 3, pp. 229-234, 2002.

[26] G. Li and C. F. Quiros, "Sequence-related amplified polymorphism (SRAP), a new marker system based on a simple PCR reaction: its application to mapping and gene tagging in Brassica," Theoretical and Applied Genetics, vol. 103, no. 2-3, pp. 455-461, 2001.

[27] H. Budak, R. C. Shearman, I. Parmaksiz, R. E. Gaussoin, T. P. Riordan, and I. Dweikat, "Molecular characterization of Buffalograss germplasm using sequence-related amplified polymorphism markers," Theoretical and Applied Genetics, vol. 108, no. 2, pp. 328-334, 2004.

[28] A. A. El-Shahed, K. F. Abdellatif, I. A. Ibrahim, A. M. Mohamed, and I. Z. Abdelsalam, "Efficiency of the new 
SRAP and TRAP markers to detect the banana somaclonal variants," Life Science Journal, vol. 14, no. 3, 2017.

[29] T. Murashige and F. Skoog, "A revised medium for rapid growth and bio assays with tobacco tissue cultures," Physiologia Plantarum, vol. 15, no. 3, pp. 473-497, 1962.

[30] N. O. Amugune, H. N. B. Gopalan, and B. Bytebier, "Leaf disc regeneration of passion fruit," African Crop Science Journal, vol. 1, no. 2, 1993.

[31] M. E. Compton, "Statistical methods suitable for the analysis of plant tissue culture data," Plant Cell, Tissue and Organ Culture, vol. 37, no. 3, pp. 217-242, 1994.

[32] M. A. Saghai-Maroof, K. M. Soliman, R. A. Jorgensen, and R. W. Allard, "Ribosomal DNA spacer-length polymorphisms in barley: mendelian inheritance, chromosomal location, and population dynamics," Proceedings of the National Academy of Sciences, vol. 81, no. 24, pp. 8014-8018, 1984.

[33] L. M. Vieira, D. I. Rocha, M. F. Taquetti et al., "In vitro plant regeneration of Passiflora setacea D.C. (Passifloraceae): the influence of explant type, growth regulators, and incubation conditions," In Vitro Cellular \& Developmental BiologyPlant, vol. 50, no. 6, pp. 738-745, 2014.

[34] F. Trevisan and B. M. J. Mendes, "Optimization of in vitro organogenesis in passion fruit (Passiflora edulis f. flavicarpa)," Scientia Agricola, vol. 62, no. 4, pp. 346-350, 2005.

[35] H. Busilacchi, C. Severin, M. Gattuso, A. Aguirre, O. Di Sapiro, and S. Gattuso, "Field culture of micropropagated Passiflora caerulea L. histological and chemical studies," Bol. Latinoam. Caribe.vol. 7, pp. 257-263, 2008.

[36] G. Pacheco, R. Garcia, D. Lugato, M. Vianna, and E. Mansur, "Plant regeneration, callus induction and establishment of cell suspension cultures of Passiflora alata Curtis," Scientia Horticulturae, vol. 144, pp. 42-47, 2012.

[37] S. B. Mukasa, A. Ssamula, P. Asami, and T. A. Holton, "In vitro propagation of three commercial passionfruit varieties in Uganda," African Crop Science Journal, vol. 24, no. 4, pp. 397-404, 2016.

[38] M. Ozarowski and B. Thiem, "Progress in micropropagation of Passiflora spp. to produce medicinal plants: a mini-review," Revista Brasileira de Farmacognosia, vol. 23, no. 6, pp. 937947, 2013.

[39] J. F. Gomez-Leyva, L. A. M. Acosta, I. G. L. Muraira, H. S. Espino, F. Ramirez-Cervantes, and I. Andrade-Gonzalez, "Multiple shoot regeneration of roselle (Hibiscus sabdariffa L.) from a shoot apex culture system," International Journal of Botany, vol. 4, no. 3, pp. 326-330, 2008.

[40] C. Ragavendran, D. Kamalanathan, G. Reena, and D. Natarajan, "In vitro propagation of nodal and shoot tip explants of Passiflora foetida L. An exotic medicinal plant," Asian Journal of Plant Science \& Research, vol. 2, no. 6, pp. 707-711, 2012.

[41] I. Couée, I. Hummel, C. Sulmon, G. Gouesbet, and A. El Amrani, "Involvement of polyamines in root development," Plant Cell, Tissue and Organ Culture, vol. 76, no. 1, pp. 1-10, 2004.

[42] A. F. M. Viu, M. A. O. Viu, A. R. Tavares, F. Vianello, and G. P. P. Lima, "Endogenous and exogenous polyamines in the organogenesis in Curcuma longa L," Scientia Horticulturae, vol. 121, no. 4, pp. 501-504, 2009.

[43] R. Parimalan, P. Giridhar, and G. A. Ravishankar, "Enhanced shoot organogenesis in Bixa orellana L. in the presence of putrescine and silver nitrate," Plant Cell Tissue and Organ Culture, vol. 105, no. 3, pp. 200-285, 2011.
[44] A. Redha and P. Suleman, "Effects of exogenous application of polyamines on wheat anther cultures," Plant Cell, Tissue and Organ Culture (PCTOC), vol. 105, no. 3, pp. 345-353, 2011.

[45] M. D. C. Vidal and E. D. Garcia, "Analysis of aMusa spp. somaclonal variant resistant to yellow Sigatoka," Plant Molecular Biology Reporter, vol. 18, no. 1, pp. 23-31, 2000. 